\title{
GAMBARAN EPIDEMIOLOGI KEJADIAN PENYAKIT DEMAM BERDARAH DENGUE DI KECAMATAN BUAH BATU KOTA BANDUNG TAHUN 2012 - 2016
}

\author{
Putri Intan Pertiwi ${ }^{*}$, Dr.M.Choiroel Anwar, SKM, M.Kes $\left.{ }^{* *}\right)$ \\ Jurusan Kesehatan Lingkungan, Politeknik Kesehatan Kemenkes Semarang, \\ Jl.Raya Baturaden KM 12 Purwokerto, Indonesia
}

\begin{abstract}
Abstrak
Demam Berdarah Dengue (DBD) meningkat seiring dengan kepadatan penduduk. Kota Bandung paling tinggi pada Kecamatan Buah Batu dengan jumlah kasus Tahun 2012 sebanyak 407 kasus, Tahun 2013 sebanyak 540 kasus, Tahun 2014 sebanyak 202 kasus, tahun 2015 sebanyak 270, dan tahun 2016 sebanyak 293 kasus. Tujuan dari KTI ini adalah menggambarkan kejadian penyakit Demam Berdarah Dengue (DBD) berdasarkan waktu, tempat dan orang juga menggambarkan cara pemberantasan penyakit DBD di Kecamatan Buah Batu. Metode penelitian yang digunakan adalah jenis penelitian Deskriptif. Hasil penelitian menunjukan kasus Demam Berdarah Dengue (DBD) di Kecamatan Buah Batu Tahun 2012-2016 tertinggi pada Bulan April sebanyak 230 kasus. Tempat persebaran paling tinggi di Kelurahan Jatisari dengan jumlah kasus IR:396,9 penderita terbanyak laki-laki sebanyak 923 kasus, terbanyak adalah golongan umur 10-14 Tahun sebanyak 613 kasus dengan pendidikan SMP dan pekerjaan pelajar. Pemberantasan dilakukan dengan cara foging bila ditemukan kasus. Kesimpulan penelitian adalah kasus tertinggi terjadi pada Bulan April, terbanyak di Kelurahan Jatisari, jenis kelamin terbanyak laki - laki tingkat pendidikan SMP pekerjaan pelajar. Saran yang dapat diberikan adalah memperbaiki perilaku, melakukan $3 M$ plus, lakukan PSN setiap bulan, gunakan lotion anti nyamuk, gunakan kelambu dan lakukan fogging bila ditemukan kasus.
\end{abstract}

Kata kunci: demam berdarah dengue, kesehatan lingkungan

\begin{abstract}
Epidemiology Overview of Dengue Hemorrhagic Fever In Buah Batu District Bandung City Year 2012-2016. Dengue Hemorrhagic Fever (DHF) increases with population density. Bandung City is the highest in Buah Batu District with the number of cases in 2012 is 407 cases, 2013 is 540 cases, 2014 is 202 cases, in 2015 is 270, and in 2016 is 293 cases. The purpose of research is to describe the incidence of Dengue Hemorrhagic Fever (DHF) based on time, place and people also describes the way of eradicated dengue disease in Buah Batu District. The research method used Descriptive research type. The results showed cases of Dengue Hemorrhagic Fever (DHF) in Buah Batu District Year 2012-2016 highest in April as many as 230 cases. The highest distribution place of case in Jatisari village with the number of IR cases: 396.9 male majority of 923 cases, most of them are 10-14 Years old as many as 613 cases with education level is junior high school and level of job is student. Eradication of case by fogging if found the case. The conclusion of the research was the highest case in April, most in Jatisari subdistrict, most case gender is male with education level is junior high school and level of job is student. Suggestions that can be given is to improve the behavior, do $3 M$ plus, do the PSN every month, use mosquito repelent, use mosquito nets and do fogging when found case.
\end{abstract}

Keywords: Dengue Hemorrhagic Fever (DHF), environmenthal health

\section{Pendahuluan}

Kesehatan merupakan hak asasi manusia dan

\footnotetext{
${ }^{*}$ E-mail: putrintanpertiwi@gmail.com

${ }^{* *}$ E-mail: choirul1960@gmail.com
}

salah satu unsur kesejahteraan yang harus diwujudkan sesuai dengan cita - cita bangsa Indonesia sebagaimana dimaksud dalam pancasila dan Undang - Undang Dasar Negara Republik Indonesia Tahun 1945 (UU RI Nomor 36 Tahun 2009) 
Epidemiologi telah di definisikan dengan berbagai cara salah satunya ilmu yang mempelajari tentang sifat, penyebab, pengendalian, dan faktor faktor yang mempengaruhi frekuensi dan distribusi penyakit kecacatan dan kematian dalam populasi manusia. Epidemiologi meliputi pemberian ciri pada distribusi status kesehatan, penyakit, atau masalah kesehatan masyarakat lainnya. Berdasarkan usia, jenis kelamin, ras, geografi, agama, pendidikan, pekerjaan, perilaku, waktu, tempat, orang dan sebagainya. Karakterisasi ini dilakukan guna menjelaskan distribusi suatu penyakit atau masalah yang terkait dengan kesehatan jika dihubungkan dengan faktor penyebab.

Sebagai metode infestigasi, epidemiologi merupakan landasan bidang kesehatan masyarakat dan pengobatan pencegahan. Epidemiologi digunakan untuk menentukan kebutuhan akan program - program pengendalian penyakit, untuk mengembangkan program pencegahan dan kegiatan perencanaan layanan kesehatan, serta untuk menetapkan pola penyakit endemik, epidemik, dan pandemik.

Menurut metode investigasi epidemiologi dibagi menjadi dua yaitu epidemiologi deskriptif dan epidemiologi analitik. Epidemiologi deskriptif yaitu studi yang mempelajari peristiwa dan distribusi penyakit. studi yang menggambarkan karakter umum sebaran suatu penyakit berdasarkan orang, tempat, dan waktu kejadian penyakit (Koes Irianto, 2014, h.3).

Pada proses penyakit menular secara umum, maka dapat dijumpai berbagai manifestasi klinik sebagai hasil proses penyakit pada individu, mulai dari gejala klinik yang tidak tampak (inapparent infection) sampai pada keadaan yang berat disertai komplikasi dan berakhir cacat atau meninggal dunia. Akhir dari proses penyakit adalah sembuh atau meninggal dunia. Penyembuhan dapat lengkap atau dapat berlangsung jinak (mild) atau dapat pula dengan gejala sisa yang berat (severe sequele) (Koes Irianto, 2014, h.12).

Demam Dengue (DD) dan Demam Berdarah Dengue (DBD) disebabkan virus Dengue yang termasuk kelompok B Arthropod Borne Virus (Arboviroses) yang sekarang dikenal sebagai genus flavivirus, famili flaviviridae, dan mempunyai empat jenis serotipe yaitu, DEN-1, DEN-2, DEN-3, DEN-4. Seseorang yang tinggal di daerah endemis Dengue dapat terinfeksi oleh 3 atau 4 serotipe selama hidupnya, keempat serotipe ditemukan dari bersirkulasi sepanjang tahun. Serotipe DEN-3 merupakan serotipe yang terbanyak berhasil di isolasi $(48,6 \%)$, disusul berturut turut DEN-2 (28,6\%), DEN-1(20\%), DEN-4 (2,9\%) (Koes Irianto, 2014, h.148)

Vektor utama penyakit DBD adalah nyamuk Aedes aegypti (di daerah perkotaan) dan Aedes albopictus (di daerah pedesaan) nyamuk yang menjadi faktor penyakit DBD adalah nyamuk yang menjadi infeksi saat menggigit manusia yang sedang sakit dan viremia (terdapat virus dalam darahnya). Menurut laporan terakhir virus dapat pula diitularkan secara transovarial dari nyamuk ketelur - telurnya. Virus berkembang dalam tubuh nyamuk selama 8-10 hari terutama dalam kelenjar air liurnya dan jika nyamuk ini menggigit orang lain maka virus Dengue akan dipindahkan bersama air liur nyamuk.

DBD pertama kali dilaporkan pada tahun 1968 di Jakarta dan Surabaya, dengan 48 penderita dan angka kematian (CFR) sebesar 41,3\%. Dewasa ini DBD telah tersebar di seluruh provinsi di Indonesia.

Program pencegahan dan pemberantasan DBD telah berlangsung lebih kurang 43 tahun dan berhasil menurunkan angka kematian dari $41,3 \%$ pada tahun 1968 menjadi $0,87 \%$ pada tahun 2010 , tetapi belum berhasil menurunkan angka kesakitan. Jumlah penderita cenderung meningkat, penyebarannya semakin luas, menyerang tidak hanya anak-anak tetapi juga golongan umur yang lebih tua. Pada tahun 2011 sampai bulan Agustus tercatat 24.362 kasus dengan 196 kematian (CFR: 0,80 \%). Berdasarkan rekapitulasi data kasus yang ada sampai tanggal 22 Agustus 2011 tercatat hanya Provinsi Bali yang masih memiliki angka kesakitan DBD diatas target nasional yaitu 55 per 100.000 penduduk.

Sepanjang tahun 2015 jumlah masyarakat Jawa Barat yang terserang penyakit demam berdarah dengue (DBD) mencapai hingga 22.071 orang. Bahkan Kota Bandung menjadi daerah paling tinggi jumlah penderitanya. Sementara selama bulan Januari 2016, jumlah pasien yang terserang DBD mencapai 172 orang. Berdasarkan data dari Bidang Bina PLPP Dinas Kesehatan Jawa Barat, jumlah pasien yang terserang DBD selama 2015 di Kota Bandung mencapai 3.640 orang. Tujuh orang di antaranya meninggal akibat penyakit DBD (Depkes RI, 2016).

Menurut data dari Dinas Kesehatan Kota Bandung pada tahun 2016 dari 30 kecamatan, terdapat 5 Kecamatan yang penderitanya lebih banyak dari Kecamatan yg lain seperti Kecamatan Rancasari dengan 206 penderita, Kecamatan Batununggal 210 penderita, Kecamatan Lengkong 226 penderita, Kecamatan Coblong 292 penderita, dan tertingga dialami Kecamatan Buah Batu sebanyak 293 kasus di tahun 2016. Jumlah ini meningkat dari tahun 2015 yang berjumlah 270 kasus. Tujuan penelitian ini adalah untuk mendeskripsikan kejadian penyakit Demam Berdarah Dengue(DBD) di Kecamatan Buah Batu Kota Bandung Tahun 2012-2016 berdasarkan orang, waktu dan tempat kejadian.

Permasalahan yang diambil adalah bagaimana gambaran kejadian penyakit Demam Berdarah Dengue (DBD) di Kecamatan Buah Batu berdasarkan orang, waktu dan tempat kejadian.

\section{Bahan dan Metode}


Jenis penelitian yang digunakan adalah penelitian deskriptif. Untuk mendapatkan gambaran kejadian objek penelitian berdasar kepada variabel epidemiologi (orang, tempat, waktu).

Lokasi penelitian dilakukan di Kecamatan buah Batu Kota Bandung. Dalam penelitian ini subjek penelitian adalah penderita penyakit Demam Berdarah Dengue (DBD) mulai dari Tahun 2012 sampai dengan Tahun 2016.

Pengumpulan data dilakukan dengan cara wawancara kepada pihak Puskesmas Margahayu Raya dan Puskesmas Sekejati menggunakan kuisioner dan menggunakan data sekunder yang didapat dari Dinas Kesehatan Kota Bandung.

Analisis data yaitu menggunakan analisis deskriptif. Data sekunder yang didapat dari Dinas Kesehatan Kota Bandung kemudian dituangkan kedalam tabel berdasarkan umur, jenis kelamin, jenis pekerjaan, dan tingkat pendidikan. Dituangkan dalam bentuk grafik perbulan dan grafik pertahun. Kemudian digambarkan wilayah persebarannya menggunakan peta wilayah.

\section{Hasil dan Pembahasan}

a. Gambaran Umum Kecamatan Buah Batu

1) Keadaan Gografis

Kecamatan Buah Batu merupakan bagian dari wilayah Bandung Timur Kota Bandung yang memiliki luas wilayah $8,14 \mathrm{Ha}$. Secara administratif kecamatan Buah Batu di batasi oleh :

Bagian Selatan :Kec.Bojong Soang Kab. Bandung

Bagian Utara :Kec.Kiaracondong dan Antapani Kot.

Bandung

Bagian Timur :Kec.Rancasari Kot. Bandung

Bagian Barat :Kec.Bandung Kidul Kot. Bandung

Secara geografis Kecamatan Buah Batu memiliki bentuk wilayah datar / berombak sebesar 75\% dari total keseluruhan luas wilayah. Ditinjau dari sudut ketinggian tanah, Kecamatan Buah Batu berada pada ketinggian $500 \mathrm{~m}$ diatas permukaan air laut. Suhu maksimum dan minimum di Kecamatan Buah Batu berkisar $30 / 28{ }^{\circ} \mathrm{C}$, sedangkan dilihat dari segi hujan berkisar $600 \mathrm{~mm} /$ th dan jumlah hari dengan curah hujan yang terbanyak sebesar 45 hari. Kecamatan Buah Batu memiliki empat kelurahan yaitu Kelurahan Cijawura, Kelurahan Margasari, Kelurahan Sekejati, dan Kelurahan Jatisari.

Dengan pembagian area tanah sebagai berikut :

Tanah Kering (daratan) $\quad: 591,6 \mathrm{Ha}$

Tanah Basah $\quad: 7,3 \mathrm{Ha}$

Fasilitas Umum $\quad: 39,15 \mathrm{H}$

Kecamatan Buah Batu memiliki dua puskesmas yaitu Puskesmas Upt Margahayu Raya dengan wilayah kerja Kelurahan Cijawura dan Kelurahan Margasari dan
Puskesmas Sekejati dengan wilayah kerja Kelurahan Sekejati dan Kelurahan Jatisari.

2) Keadaan Demografi

a) Pertumbuhan Penduduk

Kecamatan Buah Batu memiliki jumlah penduduk sebanyak 88.974 jiwa, yang terdiri dari 46.433 jiwa lakilaki dan 472.541 jiwa perempuan. Jumlah kepala keluarga (KK) di Kecamatan Buah Batu saat ini mencapai sekitar 25.279 KK. Berdasarkan luas wilayah Kecamatan Buah Batu kepadatan penduduknya mencapai 11.973 per $\mathrm{Km}^{2}$ dan dilihat dari pertumbuhan penduduk, intensitas populasinya akan terus bertambah dari waktu ke waktu.

b) Jumlah Penduduk Berdasarkan Umur

Penduduk di Kecamatan Buah Batu berjumlah 88.974 dengan penduduk tertinggi berdasarkan umur yaitu $25-29$ dengan jumlah penduduk 9.098 orang. Berikut adalah tabel jumlah penduduk berdasarkan golongan umur.

2) Keadaan Sosial Ekonomi

a) Tingkat Pendidikan

Berdasarkan data yang di dapat dari Kecamatan Buah Batu ada tingkat pendidikan paling tinggi di Kecamatan Buah Batu adalah tamatan SLTA sebanyak 17.513 dengan persentase $19,6 \%$ dan paling rendah adalah tidak tamat SD sebanyak 5.560 orang dengan persentase $6,2 \%$.

Tabel 1

Jumlah Penduduk di Kecamatan Buah Batu Kota Bandung Tahun 2012-2016

\begin{tabular}{|c|c|c|c|c|c|}
\hline \multicolumn{6}{|c|}{ Jumlah } \\
\hline No & Pendidikan & $\begin{array}{l}\text { Laki- } \\
\text { laki }\end{array}$ & $\begin{array}{c}\text { Perem } \\
\text { puan }\end{array}$ & Jumlah & $\%$ \\
\hline 1. & $\begin{array}{l}\text { Belum } \\
\text { sekolah }\end{array}$ & 4.015 & 4.465 & 8.480 & $9,5 \%$ \\
\hline 2. & $\begin{array}{l}\text { Tidak Tamat } \\
\text { SD }\end{array}$ & 2.774 & 2.786 & 5.560 & $6,2 \%$ \\
\hline 3. & $\begin{array}{l}\text { Belum tamat } \\
\text { SD }\end{array}$ & 5.048 & 4.880 & 9.928 & $\begin{array}{l}11,1 \\
\%\end{array}$ \\
\hline 4. & Tamat SD & 5.137 & 5.112 & 10.249 & $\begin{array}{l}11,5 \\
\%\end{array}$ \\
\hline 5. & Tamat SLTP & 7.920 & 6.803 & 14.723 & $\begin{array}{l}16,5 \\
\%\end{array}$ \\
\hline 6. & Tamat SLTA & 8.744 & 8.712 & 17.456 & $\begin{array}{l}19,6 \\
\%\end{array}$ \\
\hline 7. & $\begin{array}{l}\text { Akademik/Se } \\
\text { derajat }\end{array}$ & 4.866 & 3.575 & 8.441 & $9,4 \%$ \\
\hline 8. & Universitas & 7.929 & 6.208 & 14.137 & $\begin{array}{l}15,8 \\
\%\end{array}$ \\
\hline & Jumlah & $\begin{array}{l}46.43 \\
3 \\
\end{array}$ & $\begin{array}{l}42.54 \\
1\end{array}$ & 88.974 & $100 \%$ \\
\hline
\end{tabular}

Sumber : Profile Kecamatan Buah Batu

b) Jenis pekerjaan

Jenis pekerjaan penduduk di Kecamatan Buah Batu urutan lima terbanyak yaitu sebagai pelajar/mahasiswa, PNS, Pegawai Swasta, Pedagang dan Pekerjaan lain lain. Pekerjaan lain - lain adalah pekerjaan selain yang 
ada di dalam tabel yaitu seperti TNI, Dokter, Bidan, Peternak, Pengrajin, Penjahit, Tukang Kayu, Supir, Notaris dan Pengusaha. Pada Tabel 4.1 menjelaskan bahwa penduduk Kecamatan Buah Batu berdasarkan jenis pekerjaan terbanyak yaitu lain - lain dengan jumlah 29.260 orang dengan persentase $32,8 \%$ dan yang paling sedikit yaitu profesi petani sebanyak 1.423 orang dengan persentase $1,5 \%$.

Berikut adalah tabel jumlah penduduk Kecamatan Buah Batu berdasarkan jenis pekerjaan :

Tabel 2

Jumlah Penduduk di Kecamatan Buah Batu Kota Bandung Berdasarkan Jenis Pekerjaan

\begin{tabular}{|c|c|c|c|c|c|}
\hline No & $\begin{array}{l}\text { Pekerja- } \\
\text { an }\end{array}$ & $\begin{array}{c}\text { Laki } \\
- \text { laki }\end{array}$ & $\begin{array}{l}\text { Perem- } \\
\text { puan }\end{array}$ & $\begin{array}{l}\text { Jum- } \\
\text { lah }\end{array}$ & $\%$ \\
\hline 1. & Petani & 634 & 789 & 1.423 & $1,5 \%$ \\
\hline \multirow[t]{2}{*}{2.} & Pelajar/ & 11.67 & 9.780 & 21.45 & $24,1 \%$ \\
\hline & $\begin{array}{l}\text { Mahasis } \\
\text { wa }\end{array}$ & 1 & & 1 & \\
\hline 3. & $\begin{array}{l}\text { Pegawai } \\
\text { Swsata }\end{array}$ & 6891 & 6735 & $\begin{array}{l}13.62 \\
6\end{array}$ & $15,3 \%$ \\
\hline 4. & Pedagan & 1995 & 1915 & 3.910 & $4,3 \%$ \\
\hline 5. & $\begin{array}{l}\mathrm{g} \\
\text { Pegawai } \\
\text { Negeri } \\
\text { Sipil }\end{array}$ & 3780 & 3319 & 7.099 & $7,9 \%$ \\
\hline 6. & $\begin{array}{l}\text { Buruh } \\
\text { Swasta }\end{array}$ & 1.932 & 1.356 & 3.288 & $3,6 \%$ \\
\hline 7. & $\begin{array}{l}\text { Pegawai } \\
\text { BUMN }\end{array}$ & 1.924 & 1.033 & 2.957 & $3,3 \%$ \\
\hline 8. & $\begin{array}{l}\text { Pensiuna } \\
\mathrm{n}\end{array}$ & 1.560 & 1.020 & 2.580 & $2,8 \%$ \\
\hline 9. & $\begin{array}{l}\text { Wiraswa } \\
\text { sta }\end{array}$ & 1.985 & 1.395 & 3.380 & $3,7 \%$ \\
\hline \multirow[t]{2}{*}{10.} & $\begin{array}{l}\text { Lain - } \\
\text { lain }\end{array}$ & $\begin{array}{l}14.22 \\
5 \\
\end{array}$ & 15.035 & $\begin{array}{l}29.26 \\
0\end{array}$ & $32,8 \%$ \\
\hline & Jumlah & $\begin{array}{l}46.59 \\
7\end{array}$ & 42.377 & $\begin{array}{l}88.97 \\
4\end{array}$ & $100 \%$ \\
\hline
\end{tabular}

Sumber : Profil Kecamatan Buah Batu

A. Gambaran Khusus Penyakit Demam Berdarah Dengue

1. Variabel Epidemiologi Demam Berdarah Dengue Berdasarkan Waktu Kejadian

Gambar 4.1, 4.2, 4.3, 4.4 dan 4.5 menunjukkan perbedaan jumlah penderita Demam Berdarah Dengue setiap bulan, penderita paling tinggi dari tahun 2012 2016 terjadi pada Bulan April. Sedangkan kasus terendah pada Bulan Oktober. Hal ini bisa jadi dikarenakan suhu udara yang rendah sehingga menyebabkan kelembaban menjadi tinggi, selain itu dapat juga dikarenakan curah hujan yang tidak menentu sehingga terjadi genangan genangan air dan perkembangbiakan nyamuk Aedes aegypti menjadi sangat cepat.

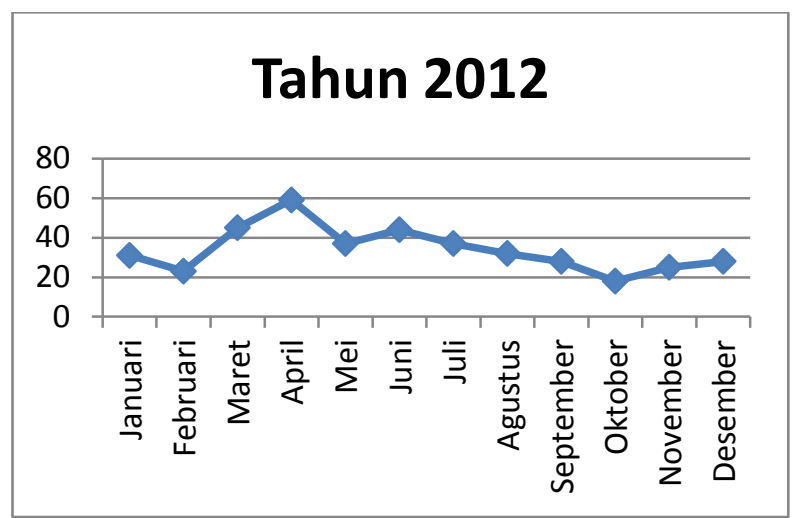

Gambar 1

Jumlah Penderita Demam Berdarah Dengue

Berdasarkan Bulan Kejadian di Kecamatan Buah Batu Kota Bandung Tahun 2012

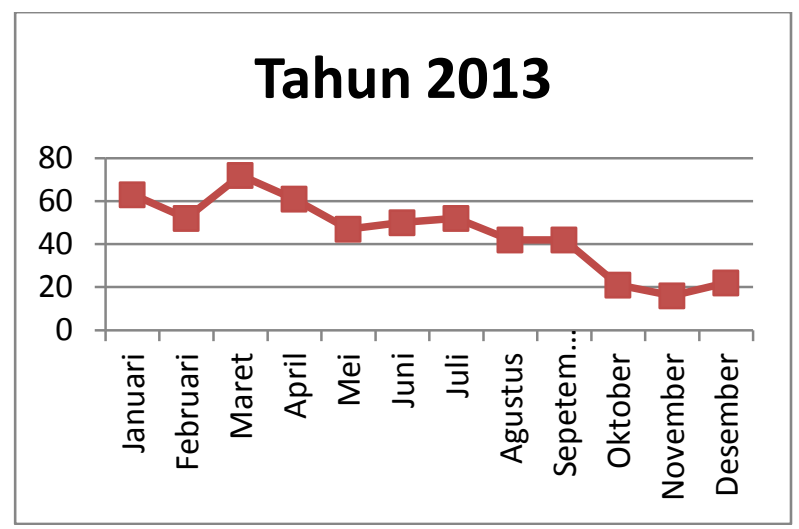

Gambar 2

Penderita Demam Berdarah Dengue

Berdasarkan Bulan Kejadian di Kecamatan Buah Batu Tahun 2013

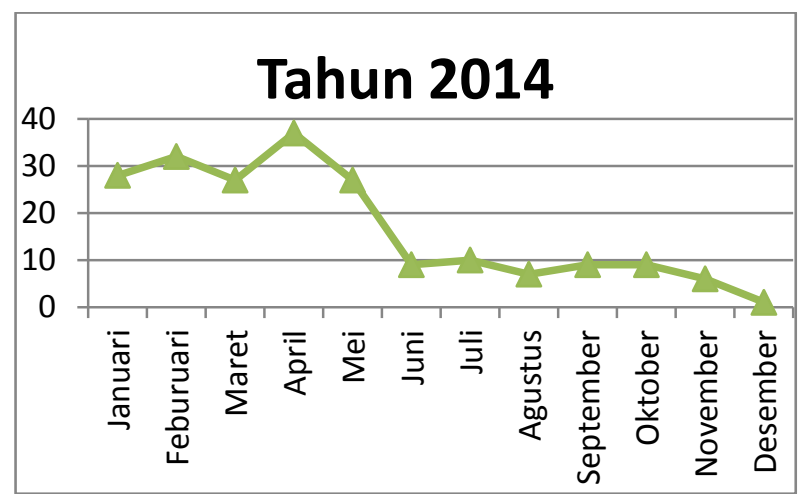

Gambar 3

Penderita Demam Berdarah Dengue

Berdasarkan Bulan Kejadian di Kecamatan Buah Batu Tahun 2014 


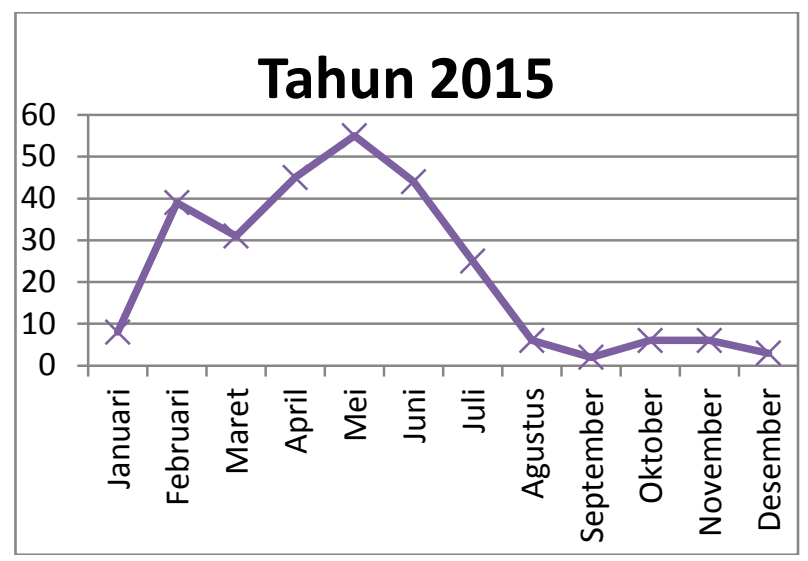

Gambar 4

Penderita Demam Berdarah Dengue

Berdasarkan Bulan Kejadian di Kecamatan Buah Batu Tahun 2015

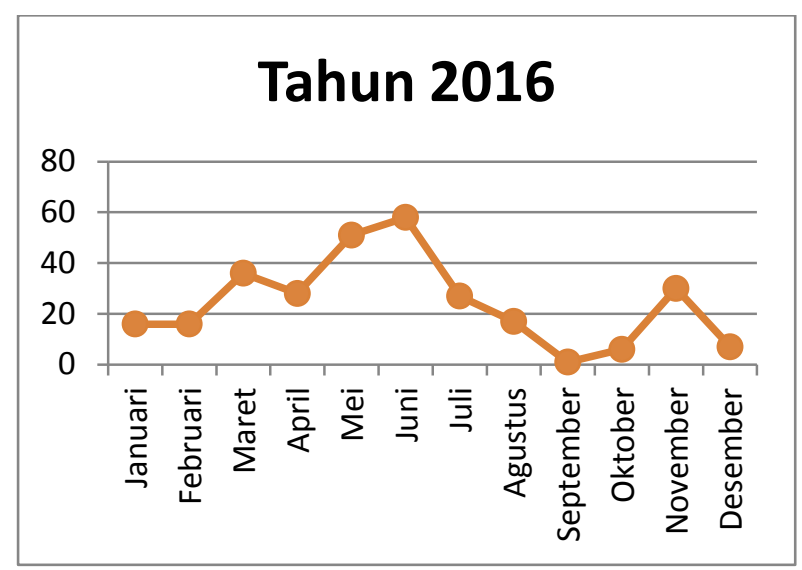

Gambar 5

Penderita Demam Berdarah Dengue

Berdasarkan Bulan Kejadian di Kecamatan Buah Batu Tahun 2016

Berikut adalah data penderita Demam Berdarah Dengue berdasarkan tahun kejadian :

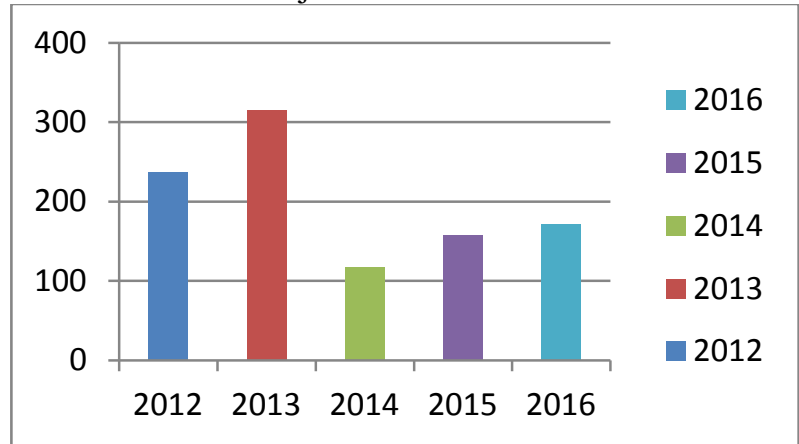

Gambar 6

Jumlah Penderita Demam Berdarah Dengue di Kecamatan Buah Batu berdasarkan Tahun Kejadian

Berdasarkan grafik tahun kejadian, Demam Bedarah Dengue tahun 2012 sebanyak 407 (IR:237,7) kasus, tahun 2013 sebanyak 540 (IR:315,4) kasus, tahun
2014 sebanyak 202 (IR:117,9) kasus, tahun 2015 sebanyak 270 (IR:157,7) kasus, dan tahun 2016 sebanyak 293 (IR:171,1) kasus. Dengan demikian dapat disimpulkan bahwa kejadian Demam Berdarah Dengue di Kecamatan Bauh Batu terendah pada tahun 2014 dengan jumlah 202 kasus. Sedangkan kasus tertinggi terjadi pada tahun 2013 dengan jumlah 540 kasus.

Di Kecamatan Buah Batu dapat dilihat nilai maximum pada Tahun 2012 yaitu Bulan April, Tahun 2013 yaitu pada Bulan Maret, Tahun 2014 yaitu pada Bulan Februari, Tahun 2015 pada Bulan Mei, dan 2016 pada Bulan Juni. Sedangkan nilai minimum pertumbuhan penyakit Demam Berdarah Dengue di Kecamatan Buah Batu tahun 2012 - 2016 terjadi bulan September dan Desember, nilai maximum terjadi pada bulan Maret.

Untuk melihat grafik pola maximal dan minimal telihat pada gafik berikut :

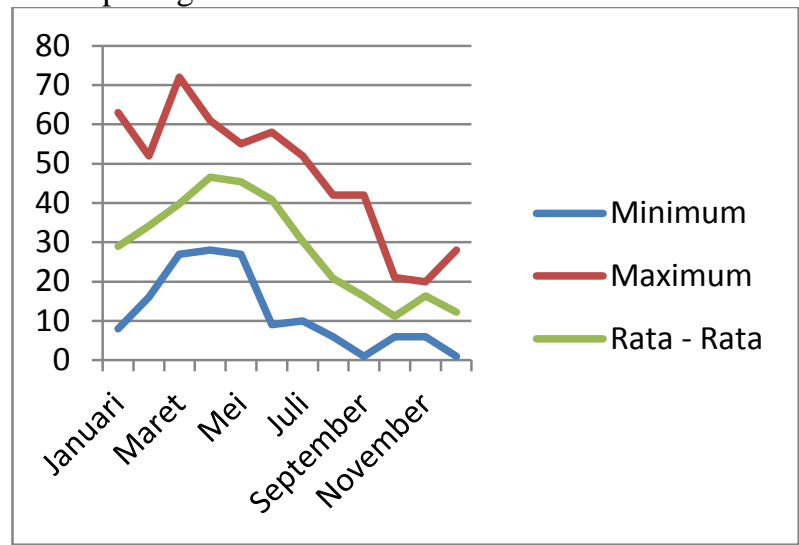

\section{Gambar 7}

Grafik Maximum dan Minimum Penderita Penyakit Demam Berdarah Dengue di Kecamatan Buah Batu Kota Bandung Tahun 2012 - 2016

2. Variabel Epidemiologi Demam Berdarah Dengue Berdasarkan Orang

a. Umur

Penderita Demam Berdarah Dengue di Kecamatan Buah Batu Kota Bandung tahun 2012 - 2016 paling tinggi adalah golongan umur $10-14$ tahun dengan jumlah penderita sebanyak 613 (IR:358) penderita, dan paling rendah adalah golongan umur $<1$ (IR:44,9) orang.

Tabel 4.5 menunjukan bahwa kasus Demam Berdarah Dengue terendah di Kecamatan Buah Batu terjadi pada kelompok umur $<1$ dengan jumlah penderita 77 orang, dan yang paling tinggi terjadi pada kelompok umur $10-14$ orang dengan jumlah penderita 613 hal ini dapat dikarenakan banyaknya aktifitas pada kelompok umur 10 -14 selain itu kekebalan tubuh pada kelompok umur $10-14$ tahun masih sangat rentan.

Menurut Ryanka (2015) umur berpengaruh terhadap penyakit Demam Berdarah Dengue, karena anak yang usianya lebih muda memiliki faktor daya tahan tubuh yang belum sempurna bila dibandingkan dengan dewasa sehingga anak beresiko terkena penyakit 
lebih tinggi termasuk terkena penyakit yang di sebabkan oleh virus dengue.

Cara yang dapat dilakukan untuk menghindari penularah penyakit Demam Berdarah Dengue pada kelompok umur 10 -14 yang rentan terhadap penularan DBD sebaiknya gunakan repllen anti nyamuk, pada saat akan pergi kesekolah dipagi hari dan sore hari agar menghindari gigitan nyamuk Aedes aegypti.

Berikut adalah tabel penderita Demam Berdarah Dengue di Kecamatan Buah Batu Kota Bandung dari tahun 2012 - 2016 berdasarkan golongan umur penderita :

\section{Tabel 3}

Jumlah Penderita Demam Berdarah Dengue Berdasarkan Golongan Umur di Kecamatan Buah Batu Kota Bandung Tahun 2012 - 2016

\begin{tabular}{|c|c|c|c|c|c|c|c|c|}
\hline No & Usia & $\begin{array}{c}20- \\
12\end{array}$ & $\begin{array}{c}20- \\
13\end{array}$ & $\begin{array}{c}\text { Tahu } \\
20- \\
14\end{array}$ & $\begin{array}{c}20- \\
15\end{array}$ & $\begin{array}{c}20- \\
16\end{array}$ & $\begin{array}{c}\text { Jum- } \\
\text { lah }\end{array}$ & IR \\
\hline 1. & $<1$ & 19 & 23 & 14 & 10 & 11 & 77 & 44,9 \\
\hline 2. & $1-4$ & 35 & 45 & 16 & 20 & 24 & 140 & 81,7 \\
\hline 3. & $5-9$ & 57 & 165 & 53 & 101 & 95 & 471 & $\begin{array}{c}275 \\
1\end{array}$ \\
\hline 4. & $\begin{array}{l}10- \\
14\end{array}$ & 62 & 243 & 79 & 111 & 118 & 613 & 358 \\
\hline 5. & $>=5$ & 234 & 64 & 40 & 28 & 45 & 411 & 240 \\
\hline \multicolumn{2}{|c|}{ Jumlah } & 407 & 540 & 202 & 270 & 293 & 1712 & 1000 \\
\hline
\end{tabular}

Sumber : Dinas Kesehatan Kota Bandung

b. Jenis Kelamin

Berdasarkan data dapat diketahui bahwa penderita paling tinggi dari tahun 2012 - 2016 menurut jenis kelamin yaitu laki - laki dengan jumlah penderita sebanyak 923 jiwa. Gambaran kejadian penyakit Demam Berdarah Dengue di Kecamatan Buah Batu dari tahun 2012 -2016 dapat dilihat pada diagram :

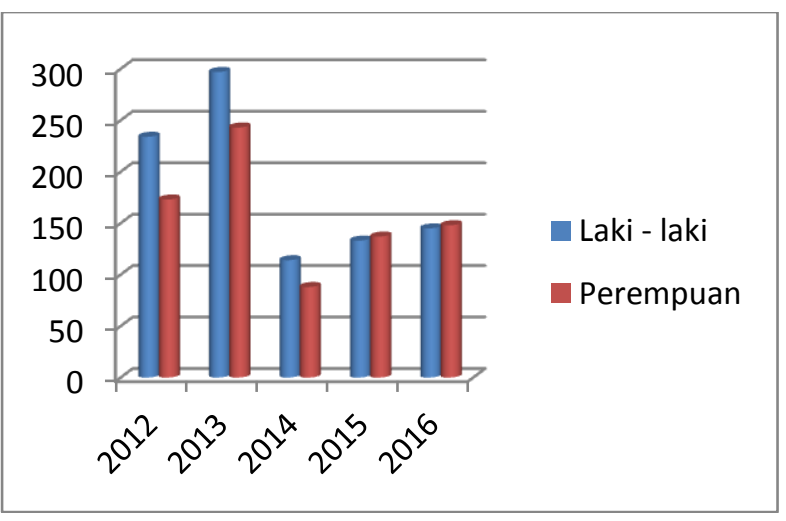

Gambar 8

Data Penyakit Demam Berdarah Dengue di Kecamatan Buah Batu Kota Bandung Tahun 2012 - 2016 c. Tingkat Pendidikan

Berdasarkan data yang di peroleh dari Dinas Kesehatan Kota Bandung penderita Demam Bedarah Dengue di Kecamatan Buah Batu paling tinggi dari tahun 2012 - 2016 adalah pendidikan Sekolah Menengah Pertama denggan jumlah penderita 630 jiwa.

Berikut adalah tabel jumlah penderita Demam Berdarah Dengue di Kecamatan Buah Batu Kota Bandung tahun 2012 - 2016 berdasarkan tingkat pendidikan penderita.

Tabel 4

Gambaran Jumlah Penderita Demam Berdarah Dengue Berdasarkan Tingkat Pendidikan Di Kecamatan Buah Batu Kota Bandung Tahun 2012 - 2016

\begin{tabular}{clll}
\hline No & \multicolumn{1}{c}{ Pendidikan } & Jumlah & Persentase \\
\hline 1. & Belum Sekolah & 217 & $12,67 \%$ \\
2. & SD & 471 & $27,51 \%$ \\
3. & SMP & 613 & $35,80 \%$ \\
4. & SMA & 299 & $17,46 \%$ \\
5. & Perguruan Tinggi & 112 & $6,54 \%$ \\
\hline & Jumlah & 1712 & $100 \%$ \\
\hline
\end{tabular}

Sumber : Dinas Kesehatan Kota Bandung

3. Variabel Epidemiologi Demam Berdarah Dengue Berdasarkan Tempat Kejadian

Tabel 5

Penderita Demam Berdarah Dengue Berdasarkan Tempat Kejadian di Kecamatan Buah Batu Kota Bandung Kot Tahun 2012 - 2016

\begin{tabular}{|c|c|c|c|c|c|c|c|}
\hline No & $\begin{array}{c}\text { Kelura } \\
\text { han }\end{array}$ & $\begin{array}{c}20- \\
12\end{array}$ & $\begin{array}{c}20- \\
13\end{array}$ & $\begin{array}{c}\text { IR } \\
20- \\
14\end{array}$ & $\begin{array}{c}20- \\
15\end{array}$ & $\begin{array}{c}20- \\
16\end{array}$ & $\begin{array}{c}\text { Jum- } \\
\text { lah }\end{array}$ \\
\hline 1. & $\begin{array}{l}\text { Kelura } \\
\text { han } \\
\text { Cijaw } \\
\text { ura }\end{array}$ & 48,4 & 44,9 & 6,4 & 28,6 & 22,7 & 151 \\
\hline 2. & $\begin{array}{l}\text { Kelura } \\
\text { han } \\
\text { Marga } \\
\text { sari }\end{array}$ & 43,2 & 88,7 & 15,1 & 27,4 & 28,6 & 203 \\
\hline 3. & $\begin{array}{l}\text { Kelura } \\
\text { han } \\
\text { Sekeja } \\
\text { ti }\end{array}$ & 85,8 & $\begin{array}{l}111, \\
5\end{array}$ & 56,6 & 45,5 & 72,4 & 371 \\
\hline 4. & $\begin{array}{l}\text { Kelura } \\
\text { han } \\
\text { Jatisari }\end{array}$ & 60,1 & 70 & 39,7 & 56 & $\begin{array}{l}171, \\
1\end{array}$ & $\begin{array}{l}396, \\
9\end{array}$ \\
\hline & lah & $\begin{array}{l}237, \\
5\end{array}$ & $\begin{array}{l}315, \\
1\end{array}$ & $\begin{array}{l}117, \\
8\end{array}$ & $\begin{array}{l}157, \\
5\end{array}$ & $\begin{array}{l}294, \\
8\end{array}$ & $\begin{array}{l}1121 \\
, 9\end{array}$ \\
\hline
\end{tabular}

Sumber : Dinas Kesehatan Kota Bandung 
Kecamatan Buah Batu memiliki luas wilayah sebesar 8,14 Ha. Pada tabel diatas menunjukan bahwa penyakit Demam Berdarah Dengue di Kecamatan Buah Batu berdasarkan wilayah penyebaran paling tinggi adalah Kelurahan Jatisari dengan 396,9 kasus, sedangkan wilayah penyebaran paling rendah adalah Kelurahan Cijawura sebanyak 151 kasus.

Berikut adalah peta wilayah Kecamatan Buah Batu dan pembagian batas wilayah antar kelurahan :

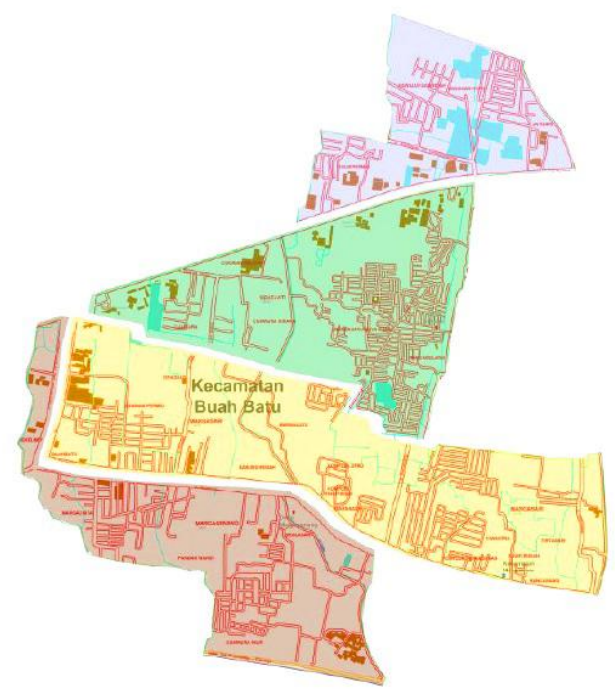

Gambar 9

Persebaran Penyakit Demam Berdarah Dengue di Kecamatan Buah Batu Tahun 2012 - 2016

(Sumber:Profil Kecamatan Buah Batu)

Keterangan :

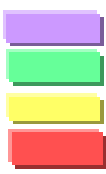
: Kelurahan Jatisari $468(396,9)$ kasus
: Kelurahan Sekejati 637 (371) kasus
: Kelurahan Margasari 346 (203) kasus
: Kelurahan Cijawura 297 (151) kasus

A. Gambaran Kejadian Penyakit Demam Berdarah Dengue Di Kecamatan Buah Batu

Kota Bandung merupakan kota metropolitan terbesar di Provinsi Jawa Barat, sekaligus menjadi Ibu Kota Provinsi tersebut. Kota ini terletak $140 \mathrm{~km}$ sebelah tenggara Jakarta. Kota Bandung termasuk dalam daerah yang beriklim tropis dengan suhu udara yang rendah dan curah hujan, kelembaban yang cukup tinggi. Hal ini dapat berpengaruh pada pertumbuhan nyamuk Aedes aegypti yang berperan sebagai carrier pembawa penyakit Demam Berdarah Dengue Kecamatan Buah Batu merupakan wilayah dengan kepadatan penduduk yang cukup tinggi sehinggi dapat berpengaruh pada persebaran penyakit Demam Baerdarah Dengue.

Kejadian penyakit Demam Berdarah Dengue di Kecamatan Buah Batu pada tahun 2012 - 2016 sebanyak 1.712 kasus. Pada tahun 2012 sebanyak 407 kasus, tahun 2013 sebanyak 540 kasus, tahun 2014 sebanyak 202 kasus, tahun 2015 sebanyak 270 kasus, dan tahun 2016 sebanyak 293 kasus.

Kecamatan Buah Batu terdiri dari empat kelurahan yaitu Kelurahan Cijawura, Kelurahan Margasari, Kelurahan Jatisari dan Kelurahan Sekejati. Pada tabel 4.7 Berdasarkan data tersebut penderita terbanyak ada pada Kelurahan Sekejati dari Tahun 2012 sampai Tahun 2014 . Pada Tahun 2015 sampai dengan Tahun 2016 kasus tertinggi terjadi di Kelurahan Jatisari.. B. Variabel Epidemiologi Demam Berdarah Dengue

1. Variabel Epidemiologi Berdasarkan Waktu Kejadian

Menurut Aris (2013) pada suhu kurang dari $16^{\circ} \mathrm{C}$ dan lebih tinggi dari $32^{\circ} \mathrm{C}$ nyamuk akan mengalami gangguan pertumbuhan, suhu optimal pertumbuhan nyamuk $25^{0}-27^{\circ} \mathrm{C}$. Adaptasi nyamuk terjadi pada kelembaban yang tinggi, sehingga begitu kelembaban rendah, nyamuk mengalami kekeringa, hal ini berdampak pada kematian populasi nyamuk akibat perubahan tingkat kelembaban ini. Pada kelembaban kurang dari $60 \%$ umur nyamuk akan menjadi lebih pendek, sehingga siklus sporogoninya tidak berbentuk. Intensitas curah hujan berpengaruh terhadap breeding site, jika sangat lebat diikut $i$ dengan angin dalam waktu yang relatif lama, justru dapat menghilangkan tempat perindukan. Hujan dengan intensitas yng tidak terlalu deras dan diselingi dengan padas, akan memperbanyak tempat perindukan, sehinggi memperbesar kesempatan nyamuk untuk berkembang biak secara optimal. Pengaruh hujan lainnya adalah bisa meningkatkan kandungan uap air diudara, sehingga kelembaban akan lebih tinggi, akibannya usia nyamuk semakin panjang, sehingga memungkinkan siklus sporogoni terbentuk.

Untuk menghindari kenaikan kasus setiap menelang Bulan April sebaiknya dilakukan PSN untuk menghindari perkembang biakan nyamuk pada tempat tempat yang mengandung banyak genangan air. PSN sebaiknya dilakukan setiap blan agar tidak ada kenaikan kasus. Selain PSN dapat juga melakukan kegiatan 3M plus untuk pencegahan penyakit Demam Berdarah Dengue. Menurut KEMENKES (2012) kegiatan pemberantasan sarang nyamuk dengan cara $3 \mathrm{M}$ Plus yaitu meliputi, 1.Menguras tempat - tempat penampungan air , seperti bak mandi/WC, drum dan sebagainya sekurang - kurangnya seminggu sekali. 2.Menutup tempat tempat penampungan air seperti gentong air/tempayan dan lain sebagainya. 3.menyingkirkan atau mendaur ulang barang - barang bekas yang dapat menampung air seperti botol plastik, kaleng, ban bekas. Plusnya yaitu mencakup ganti air vas bunga, minuman burung dan tempat tempat lain seminggu sekali. Perbaiki saluran dan talang air yang tidak lancar dan pelihara ikan pemakan jentik nyamuk.

Bentuk pengendalian pada larva nyamuk dapat dilakukan dengan cara abatisasi atau pemberian abate 
pada air biasanya dimasukan dalam bak mandi. Menurut KEMENKES (2012) larvasida adalah pengendalian larva (jenitik) nyamuk dengan pemberian insektisida yang bertujuan untuk membunuh larva. Pemberian larvasida dapat menekan kepadatan populasi untuk jangka waktu 2 bulan. Untuk pemberantasan nyamuk dewasa dapat dilakukan dengan foging setelah di temukan kasus. Menurut KEMENKES (2012) Nyamuk dewasa dapat diberantas dengan foging (pengasapan) menggunakan insektisida (racun serangga)

Pada Gambar 4.6 menjelaskan tentang jumlah penderita Demam Berdarah Dengue di Kecamatan Buah Batu terbanyak terjadi pada tahun 2013 dengan jumlah penderita sebanyak (IR:315,4). Sedangkan kejadian penyakit Demam Berdarah Dengue terendah terjadi pada tahun 2014 sebanyak (IR:117,9). Jumlah penderita Demam Berdarah Dengue di Kecamatan Buah Batu setiap tahun jumlahnya naik turun seperti terlihat pada tahun 2012 penderita sebanyak 407 (IR:237,7) lalu tahun 2013 naik menjadi 540 (IR:315,4) penderita, pada tahun 2014 turun menjadi 202 (IR:117,9) kasus, tetapi pada tahun 2015 naik menjadi 270 (IR:157,7) dan yang terakhir tahun 2016 kembali naik menjadi 293 (IR:171,1) kasus.

Tabel 4.4 menjelaskan pola maximum minimum penderita Demam Berdarah Dengue di Kecamatan Buah Batu angka maximum sebanyak 64 terjadi di Bulan April dan Angka minimum terjadi di Bulan September dan Oktober. Pada Gambar 4.7 menjelaskan tentang grafik naik turun pola maximum dan minimum.

2. Varibel Epidemiologi Berdasarkan Orang

a. Menurut Umur

Tabel 4.5 menunjukan bahwa kasus Demam Berdarah Dengue terendah di Kecamatan Buah Batu terjadi pada kelompok umur $<1$ dengan jumlah penderita 77 orang, dan yang paling tinggi terjadi pada kelompok umur 10 - 14 orang dengan jumlah penderita 613 hal ini dapat dikarenakan banyaknya aktifitas pada kelompok umur 10 -14 selain itu kekebalan tubuh pada kelompok umur 10 - 14 tahun masih sangat rentan.

Menurut Ryanka (2015) umur berpengaruh terhadap penyakit Demam Berdarah Dengue, karena anak yang usianya lebih muda memiliki faktor daya tahan tubuh yang belum sempurna bila dibandingkan dengan dewasa sehingga anak beresiko terkena penyakit lebih tinggi termasuk terkena penyakit yang di sebabkan oleh virus dengue.

Cara yang dapat dilakukan untuk menghindari penularah penyakit Demam Berdarah Dengue pada kelompok umur 10 -14 yang rentan terhadap penularan DBD sebaiknya gunakan repllen anti nyamuk, pada saat akan pergi kesekolah dipagi hari dan sore hari agar menghindari gigitan nyamuk Aedes aegypti.

b. Menurut Jenis Kelamin
Dijelaskan pada Gambar 4.8 bahwa penderita penyakit Demam Berdarah Dengue di Kecamatan Buah Batu selama kurun waktu 5 tahun dari tahun 2012 -2016 berdasarkan jenis kelamin penderita terendah yaitu perempuan dan yang tertinggi adalah laki - laki sebanyak 923 orang.

Menurut Duwi (2013) tidak ada hubungan antar jenis kelamin dengan penyakit Demam Berdarah Dengue. Dari hasil yang diperoleh sama dengan teori yang menyatakan bahwa sebagian besar penyakit menular menyerang semua jenis kelamin. Hal tersebut bisa terjadi karena sasaran nyamuk untuk menghisap darah tidak hanya laki - laki tetapi perempuanpun bisa digigit nyamuk ataupun sebaliknya, sehingga penyakit Demam Berdarah Dengue (DBD) tidak membedakan adanya jenis kelamin pada seorang anak.

Untuk pencegahan Demam Berdarah Dengue sebaiknya masyarahat mengubah perilaku seperti menggantung pakaian disembarah tempat, membiarkan adanya genangan air baik diluar maupun di dalam rumah. Membiarkan cahaya untuk masuk kedalam rumah sehingga, tidak ada potensi sarang nyamuk, selain itu dapat juga gunakan ovitrape pada tempat tempat yang gelap atau kurang cahaya, supaya nyamuk bertelur didalamnya.

c. Menurut Tingkat Pendidikan

Tabel 4.6 menjelaskan bahwa penderita Demam Berdarah Dengue terendah selama kurun waktu lima tahun dari tahun 2012 - 2016 adalah tingkat perguruan tinggi dengan jumlah penderita 112 (6,54\%) dan penderita tertinggi berdasarkan tingkat pendidikan SMP sebanyak $613(35,8 \%)$ penderita. Hal ini dapat dikarenakan kurangnya pemahaman akan bahaya Demam Berdarah Dengue dan perilaku yang masih sembarangan, contohnya seperti membuang sampah di kolong meja yang akan menjadi sarang nyamuk. Dapat juga menggunakan kelambu pada kamar tidur untuk menghindari gigitan nyamuk saat sedang tidur.

Menurut Ayong (2015), tingkat pendidikan sangat berpengaruh kepada kejadian penyakit. Semakin tinggi tingkat pendidikan responden semakin tinggi pula perannya dalam pencegahan DBD semakin rendah tingkat pendidikan responden semakin rendah pula perannya. Perbedaan tingkat pendidikan menyebabkan perbedaan pengetahuan dasar kesehatan. Semakin tinggi tingkat pendidikan, semakin mudah mereka menerima serta mengembangkan pengetahuan dan teknologi, sehingga akan meningkatkan produktivitas yang akhirnya akan meningkatkan kesehatan dan kesejahteraan keluarga.

3. Variabel Epidemiologi Berdasarkan Tempat Kejadian

Pada Tabel 4.7 menjelaskan banyaknya penderita Demam Berdarah Dengue dari tahun 2012 2016 berdasarkan masing - masing kelurahan yang ada di Kecamatan Buah Batu. Kelurahan Cijawura sebanyak 
(IR:151) kasus, Kelurahan Margasari sebanyak (IR:203) kasus, Kelurahan Sekejati (IR:371,5) kasus dan Kelurahan Jatisari (IR:396,9) kasus. Dapat disimpulkan Kelurahan yang paling rendah penderita selama tahun 2012 - 2016 adalah Kelurahan Cijawura dan kelurahan yang paling tinggi jumlah penderitanya adalah Kelurahan Jatisari. Hal ini bisa jadi dikarenakan keberadaan nyamuk yang banyak, selain itu di lingkungan Kelurahan Jatisari rumah satu dengan yang lain saling berdekatan tidak ada jarak antara rumah satu dengan yg lainnya sehingga lebih mudah untuk penularan penyakit.

Menurut Mentary (2015) Penyakit DBD dapat menyebar pada semua tempat kecuali tempat - tempat dengan ketinggian 1000 meter dari permukaan laut karena pada tempat yang tinggi dengan suhu yang rendah siklus perkembangan Aedes aegypti tidak sempurna. Meningkatnya jumlah kasus serta bertambahnya wilayah yang terjangkit disebabkan karena semakin baiknya sarana transportasi, adanya pemukiman baru dan terdapatnya vektor nyamuk hampir di seluruh wilayah di Indonesia.

Pada Gambar 4.9 menjelaskan letak wilayah kelurahan yang ada di Kecamatan buah batu berdasarkan tempat kejadian. Yang berwarna ungu adalah wilayah Kecamatan Jatisari, yang berwarna hijau adalah wilayah Kecamatan Sekejati, yang berwarna kuning adalah Kelurahan Margasari, dan yang berwarna pink adalah Kelurahan Cijawura. Berdasarkan letak Kelurahan, Kelurahan Sekejati Berada diantara Kelurahan Jatisari dan Kelurahan Margasari hal ini dapat mempengaruhi jumlah penderita pada masing - masing kelurahan.

4. Bentuk upaya yang dilakukan untuk memberantas penyakit Demam Berdarah Dengue di Kecamatan Buah Batu melakukan penyuluhan yang di jadwalkan 3 bulan sekali kepada masyarakat tentang kesehatan dan bahaya penyakit DBD, masyarakat juga dihimbau untuk melapor apabila ada kasus DBD untuk dilakukan foging. Foging dilakukan setelah ada kasus.

\section{Kesimpulan}

Berdasarkan penelitian yang telah di lakukan dapat disimpulkan sebagai berikut :

a. Penderita Demam Berdarah Dengue berdasarkan bulan kejadian tertinggi pada bulan April, dan bulan kejadian terendah pada bulan Oktober sebanyak.

b. Penderita Demam Berdarah Dengue berdasarkan tahun kejadian tertinggi pada tahun 2013 sebanyak 540 kasus, dan tahun kejadian terendah pada tahun 2014 sebanyak 202 kasus.

c. Demam Berdarah Dengue di Kecamatan Buah Batu lebih tinggi menyerang laki - laki dengan golongan umur 10 -14 dengan pendidikan SMP dan pekerjaan sebagai pelajar.

d. Penyebaran penyakit Demam Berdarah Dengue berdasarkan tempat kejadian tertinggi dari tahun
2012 - 2016 terdapat pada Kelurahan Jatisari dan kasus terendah sepanjang tahun 2012 - 2016 pada Kelurahan Cijawura.

e. Upaya yang dilakukan untuk pencegahan dan pemeberantasan penyakit Demam Beradah Dengue di Kecamatan Buah Batu yaitu melakukan penyuluhan 3 bulan sekali tentang kesehatan dan bahaya penyakit Demam Berdarah Dengue, melakukan fogging setelah ada pelaporan kasus.

Berdasarkan penelitian yang telah di lakukan dapat disarankan sebagai berikut :

a. Saran ditujukan kepada Pemerintah, meningkatkan Program penyuluhan terhadap bahaya Penyakit Demam Berdarah Dengue, beserta memberikan masukan cara pencegahan penyakit Demam Berdarah Dengue kepada masyarakat. Meningkatkan kewaspadaan setiap bulan agar menghindari kenaikan kasus tiap bulan dengan cara dilakukan PSN diseluruh kelurahan yang berada di Kecamatan Buah Batu. Menghimbau Masyarakat untuk melakukan 3M+ agar tidak ada tempat perkembangbiakan nyamuk guna pencegahan penyakit Demam Berdarah Dengue. Melakukan foging untuk pemberantasan nyamuk dewasa dapat dilakukan setelah ditemukan kasus. Lebih memperhatikan wilayah yang banyak terkena kasus Demam Berdarah Dengue untuk menghindari penularan wilayah yang lain.

b. Saran yang diberikan untuk masyaraka, mengubah perilaku yang dapat meningkatkan potensi perkembang biakan nyamuk seperti menggantung pakaian kotor disembarang tempat. Masyarakat harus lebih waspada terhadap penularan penyakit Demam Berdarah Dengue, dengan cara menggunakan lotion anti nyamuk pada pagi dan sore hari di rumah maupun saat akan keluar rumah. Gunakan kelambu pada kamar tidur untuk mencegah gigitan nyamuk saat sedang tidur. Untuk bentuk pengendalian jentik nyamuk dapat juga dilakukan dengan memelihara predator pemakan jentik seperti ikan misal ikan cupang. Untuk pengendalian jentik nyamuk dapat juga dilakukan dengancara larvasida atau abatisasi yaitu memberi insektisida pada air yg terdapat jentiknya, contoh seperti bak mandi. Untuk menambah kewaspadaan dan pencegahan dapat juga memasang ovitrap pada tempat - tempat yang kurang cahaya atau gelap, yang berfungsi untuk tempat bertelur nyamuk. Lebih waspada pada wilayah yang banyak terkena kasus Demam Berdarah Dengue untuk menghindari penularan wilayah yang lain.

\section{Daftar Pustaka}

Akhid Darwin, Aryani Pujiyanti dan Bambang Heriyanto,2013, Model Pengendalian Terpadu Vektor Demam Berdarah Dengue Di Kota Salatiga,Salatiga: Balai Besar Penelitian dan 
Pengembangan Vektor dan Reservoir Penyakit Salatiga

Arcole Margatan,1996,Mewaspadai Demam Berdarah dan Bebagai Macam Demam Lainnya,Solo:CV.Aneka

Aris Santjaka,2013,Malaria Pendekatan Model Kausalitas, Yogyakarya:Nuha Medika

Ayong Liza et al,2015,hubungan Tingkat Pengetahuan, Pendidikan dan Sikap dengan Partisipasi Ibu Rumah Tangga Dalam Pencegahan Wabah DBD di Kecamatan Kuta Alam Banda Aceh

Aziz Alimul Hidayat,2007,Metode Penelitian Kebidanan dan Teknik Analisis Data,Jakarta:Salemba Medika

BPS Kota Bandung Tahun 2015 tentang Profil Kecamatan Buah Batu

Departemen Kesehatan RI Direktorat Jendral PPM dan PLP,2012,Petunjuk Teknis Pemberantasan Sarang Nyamuk Demam Berdarah Dengue (DBD) Oleh Juru Pemantau Jentik (Jumantik),Jakarta:Dirjen PPM dan PLP

Dinas Kesehatan Kota Bandung tahun 2016 tentang Penderita Demam Berdarah Berdasarkan Waktu Kejadian, Tempat Kejadian dan Penderita dari Tahun $2012-2016$

Duwi Silvarianto,2013,Faktor - Faktor yang Berpengaruh dengan Degue Syok Syndrom (DSS) Pada Anak dengan Demam Berdarah Dengue (DBD)

Firdaus J. Kunoli,2013,Pengantar Epidemiologi Penyakit Manular Untuk Mahasiswa Kesehatan Masyarakat, Jakarta:CV. Trans Info Media

http://digilib.unila.ac.id/1376/7/BAB\%20II.pdf. Diakses pada tanggal 10 Januari 2017 pukul 22:20 WIB

http://digilib.unimus.ac.id/files/disk1/125/jtptunimusgdl-restiapriy-6232-2-babii.pdf

http://entnemdept.ufl.edu/searchresult/?q=image+of+aedes+albopictus

http://jurnalkesehatanmasyarakat.blogspot.co.id/2011/12 /faktor-yang-mempengaruhi-terjadinya.html. Diakses pada tanggal 7 Januari 2017 pukul 22:10 WIB http://repository.usu.ac.id/bitstream/123456789/57015/4 /Chapter\%20II.pdf.Diakses pada 16 Januari 2017 pukul 20:17 WIB

http://web.unair.ac.id/admin/file/f 17960 Epidemiologi. pdf. Diakses pada 6 Januari 2017 pukul 22:00 WIB

http://www.depkes.go.id/article/view/15011700003/dem am-berdarah-biasanya-mulai-meningkat-dijanuari.html. Diakses pada tanggal 7 Januari 2017 pukul 21:00 WIB

http://www.depkes.go.id/article/view/15011700003/dem am-berdarah-biasanya-mulai-meningkat-di-

januari.html\#sthash.fwWPe1v6.dpuf. Diakses pada tanggal 16 Januari 2017 pukul 19:48 WIB

http://www.depkes.go.id/article/view/16020900002/ken dalikan-dbd-dengan-psn-3m-plus.html

https://entomologytoday.org/2016/06/29/controlling-theasian-tiger-mosquito-a-potential-zika-vector-ispossible-but-difficult/

https://mediskus.com/penyakit/ciri-ciri-nyamuk-demamberdarah-disertai-gambar

Koes Irianto,2014,Epidemologi penyakit Menular \& Tidak Menular Panduan Klinis, Bandung:Alfabeta

Nur Nasry Noor,2006,Pengantar Epidemiologi Penyakit Menular,Jakarta:PT Rineka Cipta

Profil Kecamatan Buah Batu tahun 2015 dan Peta Wilayah Kecamatan Buah Batu.

Rahma Jayanti,2010,Studi Epidemiologi Demam Berdarah Dengue di Kecamatan Purwokerto Selatan,Purwokerto:Prodi DIII Kesehatan Lingkungan Politeknik Kesehatan Kemenkes Semarang

Ryanka R et al,2015,Hubungan Karakteristik Pasien Demam Berdarah Dengue (DBD) dengan Kejadian Dengue Syok Sindrome (DSS) pada Anak,Bandung:Universitas Islam Bandung

Soedarto,2009,Penyakit Menular di Indonesi, Jakarta:CV Sagung Sero

Undang- Undang Nomor 36 tahun 2009 tentang Kesehatan 